\section{Incidence of metabolic syndrome and related diseases in the Khisêdjê indigenous people of the Xingu, Central Brazil, from 1999-2000 to 2010-2011}

\author{
Incidência de síndrome metabólica e doenças \\ associadas na população indígena Khisêdjê do \\ Xingu, Brasil Central, no período de 1999-2000 \\ a 2010-2011
}

\section{Incidencia del síndrome metabólico y enfermedades relacionadas en la población indígena Khisêdjê del Xingú, Brasil Central, de 1999-2000 a 2010-2011}

Lalucha Mazzucchetti 1

Patrícia Paiva de Oliveira Galvão 1

Mario Luiz da Silva Tsutsui 1

Kennedy Maia dos Santos 1

Douglas Antônio Rodrigues 1

Sofia Beatriz Mendonça 1

Suely Godoy Agostinho Gimeno ${ }^{1}$

\author{
1 Universidade Federal de São \\ Paulo, São Paulo, Brasil. \\ Correspondence \\ L. Mazzucchetti \\ Universidade Federal de São \\ Paulo \\ Rua Botucatu 740, 4o andar \\ São Paulo, SP \\ 04023-900, Brasil. \\ lalucha@terra.com.br
}

\begin{abstract}
The aim of this study was to identify the incidence of metabolic syndrome and related diseases in the Khisêdjê population living in the Xingu Indigenous Park, Mato Grosso State, Brazil, from 1999-2000 to 2010-2011. The study included 78 individuals aged $\geq 20$ years. Data were analyzed using Student t test, linear regression, and Poisson regression. In 10 years of follow-up, cumulative incidence rates were $37.5 \%$ for metabolic syndrome, $47.4 \%$ for hypetriglyceridemia, 38.9\% for arterial hypertension, 32\% for central obesity, $30.4 \%$ for excess weight, 29.1\% for hypercholesterolemia, 25\% for low HDLc, 10.4\% for high LDLc, and 2.9\% for diabetes mellitus. Age proved to be a risk factor for incidence of hypertension, diabetes, and elevated LDLc, regardless of gender; male gender was a protective factor against incidence of central obesity, independently of age. The study showed deterioration of most target health indicators and exposure of the Khisêdjê to high cardiometabolic risk. These results may be related to changes in traditional lifestyle.
\end{abstract}

Metabolic Syndrome X; Chronic Disease; Indigenous Peoples; Incidence

\section{Resumo}

O objetivo deste estudo foi identificar a incidência de síndrome metabólica e doenças associadas na população Khisêdjê, residente no Parque Indígena do Xingu, Mato Grosso, Brasil, ao longo do período de 1999-2000 a 2010-2011. Foram incluídos 78 indivíduos com idades $\geq 20$ anos. Os dados foram avaliados por meio do teste $t$ de Student, regressão linear múltipla e regressão de Poisson. Em dez anos de seguimento verificou-se a incidência acumulada de 37,5\% de síndrome metabólica, 47,4\% de hipetrigliceridemia, 38,9\% de hipertensão arterial, $32 \%$ de obesidade central, 30,4\% de excesso de peso, 29, $1 \%$ de hipercolesterolemia, 25\% de baixo HDLc, 10,4\% de elevado LDLc e 2,9\% de diabetes mellitus. A idade foi identificada como um fator de risco para incidência de hipertensão arterial, diabetes mellitus e elevado LDLc, independentemente do sexo; ser do sexo masculino foi fator de proteção para incidência de obesidade central, não importando a idade. Identificou-se deterioração de grande parte dos indicadores de saúde avaliados, estando os Khisêdjê expostos a elevado risco cardiometabólico. Esse resultado pode estar relacionado a alterações no estilo de vida tradicional.

Síndrome X Metabólica; Doença Crônica; População Indígena; Incidência 


\section{Introduction}

The health profile of Brazilian indigenous peoples has undergone important changes over the years. Alterations in the family and social economy and the incorporation of new eating habits and customs have predisposed to an increase in chronic non-communicable diseases (CNCD), thereby deteriorating the health status and thus the quality of life of these populations $1,2,3,4,5,6,7,8,9,10,11$.

Metabolic syndrome is a CNCD that can be defined as the simultaneous presence of at least three altered metabolic parameters: central obesity, glucose intolerance, arterial hypertension, hypertriglyceridemia, or low HDL cholesterol 12. Its clinical relevance is due to the fact that affected individuals present 1.5 to 2.5 times the risk of death from all causes or from cardiovascular diseases when compared to those without the syndrome 13,14. Although not essential for the diagnosis, other disease conditions such as generalized obesity, hyperuricemia, hypercholesterolemia, and elevated LDLc are reported as associated or aggravating factors for metabolic syndrome.

Although the numerous health risks and problems resulting from metabolic syndrome are known, few related studies have been done in Brazilian indigenous peoples. The available publications report prevalence rates ranging from $11 \%$ to $65 \% 7,8,10,11,15,16$. Data on the incidence of this syndrome or its evolution over the years in a single indigenous people have not been found thus far.

Likewise, no information is available on the incidence of diseases related to metabolic syndrome in Brazilian indigenous peoples. It is only known that cases of excess weight and alterations in blood pressure, glucose tolerance, or serum lipid concentrations, which were all rare decades ago, now appear reported in the literature with similar or greater frequency when compared to rates observed in the non-indigenous Brazilian population 1,4,5,9,10,11,15,17,18,19,20.

Considering the high prevalence rates of CNCD reported in Brazilian indigenous peoples, the health problems resulting from these diseases, especially from metabolic syndrome, and the scarcity of scientific data on this subject, the current study aimed to estimate the incidence of metabolic syndrome and associated diseases in the Khisêdjê population living on the Middle Xingu River (Xingu Indigenous Park) over ten years of follow-up.

\section{Material and methods}

This was a cohort-type epidemiological study based on two cross-sectional studies among the Khisêdjê people in the years 1999-2000 and 2010-2011.

The Suyá, or Khisêdjê as they call themselves, are the only people of the Jê language that live in the Xingu Indigenous Park. According to the pattern in this linguistic family, their villages are arranged in a circular layout, with the "men's house" in the center and the other huts facing toward it. They are currently distributed in five villages: the largest, Ngôjwêre, and Ngôsokô, Roptôtxi, Beira Rio, and Terra Indígena Wawi 21. The two stages of this study were done in the main village, Ngôjwêre.

In 1999-2000, 86 Khisêdjê individuals of both genders and 20 years or older were examined (91.5\% of the total number of eligible individuals) 8, and of these, $78(90.7 \%)$ were reevaluated in 2010-2011 and therefore included in this study. Among the subjects not examined in 2010-2011 $(\mathrm{n}=8$ ), six were not located (possibly having changed villages) and two were absent at the time of the data collection.

The data collection routines used in 19992000 have been published previously ${ }^{8}$. Briefly, duplicate anthropometric data were obtained by properly trained professionals, and laboratory tests were performed after 10 hours of fasting With the exception of blood glucose, which was measured by the capillary test, all the other tests were performed in venous blood samples.

In 2010-2011 the Khisêdjê were contacted and identified by the medical cards used by the health team from the Federal University of São Paulo (UNIFESP). A standard data collection form was used. Anthropometric measurements were taken according to procedures recommended by the World Health Organization (WHO). Body mass index (BMI) was calculated as weight (in kilograms) divided by height (in meters) squared. Excess weight was defined as $\mathrm{BMI} \geq 25.0 \mathrm{~kg} / \mathrm{m}^{2} 22$. Central obesity was defined according to the cutoff points set by the WHO (waist circumference $\geq$ $80.0 \mathrm{~cm}$ for women or $\geq 94.0 \mathrm{~cm}$ for men) 23 . These measurements were taken with a portable scale, Líder brand, model P200m (Líder Balanças, Araçatuba, Brazil), with a capacity of $200 \mathrm{~kg}$ and accurate to 50g; a portable platform stadiometer, WCS brand (Cardiomed, Curitiba, Brazil), with a scale from 20 to $220 \mathrm{~cm}$; and a flexible fiberglass tape measure (TBW, China) with a scale from 0 to $150 \mathrm{~cm}$.

Laboratory tests were taken in the morning after 12 hours of fasting. The biological material (blood) was collected, processed, and stored (in 
a freezer at $-20^{\circ} \mathrm{C}$ ) in the village until sending to São Paulo. Transportation was done over land in a portable freezer for transporting heat-sensitive material (model FCW 20 EK; Domestic Medical Systems, UK). Samples were analyzed by the Central Laboratory of the São Paulo Hospital.

Systolic and diastolic blood pressure ((SBP and DBP) were measured with an automatic arm-adjusted arterial blood pressure monitor (model HEM 742-INT; OMRON Healthcare, China), after resting for 10 minutes in the sitting position. Three measurements were taken, and the final value was taken as the mean of the latter two measurements. Classification of individuals used the consensus definition of metabolic syndrome proposed by the International Diabetes Federation (IDF), American Heart Association (AHA), National Heart, Lung and Blood Institute (NHLBI), World Heart Federation (WHF), International Atherosclerosis Society (IAS), and International Association for Study of Obesity (IASO) in the year 2009 12. Hypertension was defined as $\mathrm{SBP} \geq 130.0 \mathrm{mmHg}$ or $\mathrm{DBP} \geq 85.0 \mathrm{mmHg}$.

The capillary blood glucose test used Kit One Touch Ultra 2 (Johnson \& Johnson, São Paulo, Brazil) and the same brand of lancets and strips. Collection followed the manufacturer's recommended procedures. Individual glucose tolerance classification used the guidelines of the American Diabetes Association 24, with the corrections proposed by the WHO for capillary blood glucose 25 . Thus, fasting blood glucose $\geq$ $100 \mathrm{mg} / \mathrm{dL}$ and $<110 \mathrm{mg} / \mathrm{dL}$ was classified as altered fasting blood glucose and $\geq 110 \mathrm{mg} / \mathrm{dL}$ as diabetes mellitus.

Total cholesterol, high-density lipoprotein (HDLc), and triglycerides were determined by the colorimetric enzymatic method (OLYMPUS AU 640; Tek Medical, London, UK). Low-density lipoprotein (LDLc) was measured according to the formula by Friedwald et al. 26. Presence of dyslipidemia was defined according to the values proposed by the National Cholesterol Education Program Expert Panel 27, i.e., total cholesterol > $200 \mathrm{mg} / \mathrm{dL}$ or triglycerides $>150 \mathrm{mg} / \mathrm{dL}$ or LDLc $>130 \mathrm{mg} / \mathrm{dL}$ or HDLc $<40 \mathrm{mg} / \mathrm{dL}$ for men and $<$ $50 \mathrm{mg} / \mathrm{dL}$ for women.

Determination of uric acid used the colorimetric enzymatic method (OLYMPUS AU 640). Hyperuricemia was defined as serum uric acid $>6 \mathrm{mg} / \mathrm{dL}$ for women and $>7 \mathrm{mg} / \mathrm{dL}$, for men 28 .

Identification of metabolic syndrome used the consensus criteria proposed by various organizations in 2009. Diagnosis of the syndrome was defined as the presence of at least three of the following: increased waist circumference, elevated fasting blood glucose, arterial hypertension, reduced HDL, and hypertriglyceridemia; use of medication to treat the above-mentioned diseases characterized their diagnosis 12 . The cutoff points have already been reported.

Importantly, the data presented here and referring to 1999-2000 were obtained from the file used in a PhD thesis 8,29 . In order to allow comparison of the results from 1999-2000 and 2010-2011, the variables were reclassified. Thus, all the outcomes were classified using the same cutoffs in the two study phases (1999-2000 and 2010-2011).

The data description used measures of central tendency and dispersion for the quantitative variables. Comparison of mean values for the biological variables in the same individuals used the Student t test for dependent (matched) pairs 30 . Multiple linear regression was used to analyzed 11 distinct outcomes. Each model included an outcome variable (anthropometric, physical, or laboratory) and two exposure variables [gender and age in 1999-2000, in years (continuous)]. Each outcome was measured by the following equation: value obtained in 20102011 minus value obtained in 1999-2000, divided by value obtained in 1999-2000. This stage of the data analysis included all the individuals with or without the target outcomes in 1999-2000.

Cumulative incidence was calculated considering only the individuals without the nutritional condition or chronic disease in 1999-2000 and that were thus at risk of becoming cases over the 10 years between the two evaluations. The study design did not allow calculating the incidence rates, due to the lack of information on personyears of exposure.

Poisson regression with robust variance was used to analyze nine distinct outcomes (number of new cases). Each model consisted of an outcome variable (nutritional condition or chronic disease) and two exposure variables [gender and age in 1999-2000, in years (continuous)]. This analysis only included individuals that did not present the target outcomes in 1999-2000. All stages of the analysis used Stata (Stata Corp., College Station, USA).

The current study is part of a larger project entitled Nutritional and Metabolic Profile of the Khisêdjê Indigenous People, approved by the Brazilian National Commission on Research Ethics (CONEP) and the Ethics Research Committee of UNIFESP (case review 760/10). In order to further comply with ethical guidelines, this specific study was submitted to and approved by the Ethics Research Committee of UNIFESP (case review 319/11).

In order to obtain approval by the Khisêdjê people, they were provided with an explanation of the study's objectives and procedures. Indig- 
enous translators helped explain the study to the community in the native language. Signatures were collected simultaneously with a statement by the indigenous leaders who expressed their agreement with the study. Considering Resolution 196/96 of the Brazilian National Health Council, item IV.3 line "e", providing that "in culturally differentiated communities, including indigenous peoples, advance agreement by the community should be obtained through their own leaders, but without ruling out efforts to obtain individual consent," and given the particular characteristics of these research subjects, whenever possible a free and informed consent form was obtained with signatures by the participants.

The study was funded by the São Paulo State Research Foundation (FAPESP; grant 2010/52263-7).

\section{Results}

Of the 78 individuals included in the study, 36 (46.2\%) were females and 42 (53.8\%) males. Mean age in $1999-2000$ was 36.3 years $(S D=13.4)$. There was no significant age difference between the genders in either study phase.

Table 1 shows the mean values for the anthropometric, physical, and laboratory variables for the Khisêdjê according to gender in both periods.
Comparison of the mean values shows that in females, only arm circumference and DBP failed to show statistically significant alterations over the years; the increase in mean HDLc and decrease in LDLc can be considered beneficial. In males, only LDLc failed to show a significant change; the reduction in DBP and increase in HDLc can also be considered beneficial.

As shown in Table 2, for women the outcomes SBP ( $\beta=0.0046 \mathrm{mmHg}$; 95\%CI: 0.0003; 0.0089), total cholesterol ( $\beta=0.0073 \mathrm{mg} / \mathrm{dL}$; 95\%CI: 0.0011 ; 0.0136), HDLc ( $\beta=0.0218 \mathrm{mg} / \mathrm{dL}$; 95\%CI: 0.0143 ; $0.0294)$, and LDLc ( $\beta=0.0080 \mathrm{mg} / \mathrm{dL} ; 95 \% \mathrm{CI}$ : $0.0011 ; 0.0148)$ increased with age. In males, while BMI $\left(\beta=-0.0019 \mathrm{~kg} / \mathrm{m}^{2} ; 95 \% \mathrm{CI}\right.$ : -0.0034 $-0.0005)$ decreased with age (in years), SBP ( $\beta=0.0083 \mathrm{mmHg} ; 95 \% \mathrm{CI}: 0.0043 ; 0.0123$ ) and DBP ( $\beta=0.0057 \mathrm{mmHg}$; 95\%CI: 00.0027; 0.0088) increased.

Table 3 shows the number of new cases of nutritional conditions or chronic diseases over the course of 10 years. Females showed higher cumulative incidence than males for metabolic syndrome ( $48.1 \%$ vs. $27.6 \%)$, central obesity $(60 \%$ vs. $20 \%)$, and elevated LDLc (19\% vs. 3.7\%). Meanwhile, males showed higher incidence than females for arterial hypertension (41.7\% vs. $36.2 \%$ ) hypercholesterolemia (33.3\% vs. $24 \%$ ), and hyperuricemia (21.9\% vs. $5.9 \%$ ).

Table 4 shows the incidence ratios for nutritional conditions or chronic diseases, adjusted

Table 1

Number of Khisêdjê indigenous individuals evaluated in 1999-2000 and in 2010-2011 and mean values for anthropometric, physical, and laboratory variables according to gender and year of data collection. Xingu Indigenous Park, Central Brazil, 2013.

\begin{tabular}{|c|c|c|c|c|c|c|c|c|}
\hline \multirow[t]{3}{*}{ Variables } & \multicolumn{4}{|c|}{ Females } & \multicolumn{4}{|c|}{ Males } \\
\hline & $\mathrm{n}$ & $1999-2000$ & 2010-2011 & $\mathrm{p}$-value * & $\mathbf{n}$ & $1999-2000$ & 2010-2011 & p-value * \\
\hline & & Mean (SD) & Mean (SD) & & & Mean (SD) & Mean (SD) & \\
\hline BMI (kg/m²) & 35 & $23.1(2.9)$ & $24.3(3.6)$ & 0.0128 & 42 & $25.8(2.9)$ & $26.2(3.7)$ & 0.0389 \\
\hline Waist circumference $(\mathrm{cm})$ & 35 & $82.4(7.1)$ & $88.1(8.9)$ & 0.0001 & 41 & $84.8(11.1)$ & $90.7(8.4)$ & $<0.0001$ \\
\hline Arm circumference $(\mathrm{cm})$ & 35 & $27.3(2.5)$ & $27.7(3.3)$ & 0.1927 & 42 & $29.0(5.0)$ & $30.7(3.0)$ & 0.0168 \\
\hline $\mathrm{SBP}(\mathrm{mmHg})$ & 36 & $103.5(9.3)$ & $120.1(18.9)$ & $<0.0001$ & 39 & $114.9(11.2)$ & $125.7(17.1)$ & 0.0019 \\
\hline $\mathrm{DBP}(\mathrm{mmHg})$ & 36 & $65.7(6.4)$ & $67.8(9.9)$ & 0.1036 & 39 & $72.5(6.5)$ & $66.3(8.7)$ & 0.0006 \\
\hline Fasting blood glucose (mg/dL) & 33 & $85.2(7.8)$ & $89.9(10.4)$ & 0.0125 & 36 & $85.1(8.3)$ & $92.4(8.2)$ & 0.0007 \\
\hline Total cholesterol (mg/dL) & 34 & $176.7(42.0)$ & $189.2(54.2)$ & 0.0389 & 36 & $172.0(31.5)$ & $187.4(28.3)$ & 0.0003 \\
\hline $\mathrm{HDLc}(\mathrm{mg} / \mathrm{dL})$ & 34 & $34.3(10.2)$ & $43.9(11.8)$ & $<0.0001$ & 36 & $25.6(6.7)$ & $39.4(7.4)$ & $<0.0001$ \\
\hline LDLc (mg/dL) & 32 & $122.7(37.7)$ & $111.0(43.1)$ & 0.0218 & 31 & $104.9(29.2)$ & $103.5(22.5)$ & 0.3525 \\
\hline Triglycerides (mg/dL) & 34 & $122.1(72.8)$ & $188.4(105.4)$ & $<0.0001$ & 36 & $192.3(97.4)$ & $242.3(146.8)$ & 0.0331 \\
\hline Uric acid (mg/dL) & 34 & $3.8(0.8)$ & $4.5(1.0)$ & $<0.0001$ & 36 & $5.8(1.2)$ & $6.5(1.5)$ & $<0.0001$ \\
\hline
\end{tabular}

SD: standard deviation; BMI: body mass index; SBP: systolic blood pressure; DBP: diastolic blood pressure; HDLc: high-density lipoprotein; LDLc: low-density lipoprotein.

* Matched Student t test. 
$\beta$ coefficient for age (linear regression) and $95 \%$ confidence interval $(95 \% \mathrm{Cl}$ ) for anthropometric, physical, and laboratory variables (independent models for each variable) in Khisêdjê indigenous individuals evaluated in 1999-2000 and 2010-2011, according to gender. Xingu Indigenous Park, Central Brazil, 2013.

\begin{tabular}{|c|c|c|c|c|}
\hline \multirow[t]{2}{*}{ Variables } & \multicolumn{2}{|c|}{ Females * } & \multicolumn{2}{|c|}{ Males * } \\
\hline & Age coefficient (years) & $95 \% \mathrm{Cl}$ & Age coefficient (years) & $95 \% \mathrm{Cl}$ \\
\hline $\mathrm{BMI}\left(\mathrm{kg} / \mathrm{m}^{2}\right) * \star$ & -0.0019 & $-0.0053 ; 0.0015$ & -0.0019 & $-0.0034 ;-0.0005$ \\
\hline Waist circumference $(\mathrm{cm}) * \star$ & -0.0007 & $-0.0035 ; 0.0019$ & -0.0032 & $-0.0069 ; 0.0005$ \\
\hline Arm circumference $(\mathrm{cm}) * \star$ & -0.0010 & $-0.0038 ; 0.0018$ & -0.0029 & $-0.0146 ; 0.0088$ \\
\hline $\mathrm{SBP}(\mathrm{mmHg}) * \star$ & 0.0046 & $0.0003 ; 0.0089$ & 0.0083 & $0.0043 ; 0.0123$ \\
\hline $\mathrm{DBP}(\mathrm{mmHg}) \star \star$ & -0.0019 & $-0.0055 ; 0.0017$ & 0.0057 & $0.0027 ; 0.0088$ \\
\hline Fasting blood glucose (mg/dL) ** & 0.0013 & $-0.0022 ; 0.0047$ & 0.0001 & $-0.0044 ; 0.0045$ \\
\hline Total cholesterol $(\mathrm{mg} / \mathrm{dL}) * \star$ & 0.0073 & $0.0011 ; 0.0136$ & -0.0023 & $-0.0064 ; 0.0018$ \\
\hline $\mathrm{HDLc}(\mathrm{mg} / \mathrm{dL}) * \star$ & 0.0218 & $0.0143 ; 0.0294$ & 0.0014 & $-0.0066 ; 0.0095$ \\
\hline $\operatorname{LDLc}(\mathrm{mg} / \mathrm{dL}) * \star$ & 0.0080 & $0.0011 ; 0.0148$ & -0.0006 & $-0.0065 ; 0.0053$ \\
\hline Triglycerides $(\mathrm{mg} / \mathrm{dL})$ ** & -0.0154 & $-0.0394 ; 0.0086$ & -0.0319 & $-0.0683 ; 0.0045$ \\
\hline Uric acid $(\mathrm{mg} / \mathrm{dL}) * \star$ & 0.0052 & $-0.0015 ; 0.0118$ & -0.0011 & $-0.0057 ; 0.0035$ \\
\hline
\end{tabular}

SD: standard deviation; BMI: body mass index; SBP: systolic blood pressure; DBP: diastolic blood pressure; HDLc: high-density lipoprotein; LDLc: low-density lipoprotein.

* Multiple linear regression adjusted for age in years (continuous) in 1999-2000, according to gender;

** (value for variable in 2010-2011 - value for variable in 1999-2000)/value for variable in 1999-2000.

simultaneously for age (in years) and gender. Independently of gender, relative risk was 1.03 (95\%CI: 1.01 ; 1.05) for arterial hypertension, 1.04 (95\%CI: $1.01 ; 1.07)$ for diabetes mellitus, and 1.10 (95\%CI: 1.04; 1.17) for elevated LDLc. Meanwhile, the analysis in males identified a reduction in the incidence of central obesity $(\mathrm{RR}=0.33 ; 95 \% \mathrm{CI}$ : $0.15 ; 0.72$ ), independently of age. Due to the small number of new cases, low HDLc $(n=1)$ was excluded from the analysis.

\section{Discussion}

Ever since the Khisêdjê people first came to the Xingu Indigenous Park, they have maintained good relations with the neighboring towns and have thus intensified their contact with adjacent society. Over the years they have achieved important victories such a population comeback, influenced by moderate birth rates, a drop in mortality, and a negative migratory coefficient, but they have also been exposed to high CNCD rates, identified by cross-sectional studies in 1999-2000 and 2010-2011 8,16,31,32.

The current study showed that in the ten years between the two evaluations, 21 (37.5\%) new cases of metabolic syndrome occurred, and that incidence was higher in females, with a total of 13 (48.1\%) new cases. Incidence of metabolic syndrome was not significantly associated with gender or age. No studies have been identified thus far that have evaluated the incidence of metabolic syndrome in Brazilian indigenous peoples, to serve as a source of comparison.

Metabolic syndrome is an important CNCD which is related to increased risk of cardiovascular diseases, diabetes mellitus, and all-cause mortality, among numerous other harms. Early detection thus allows the possibility of treatment and consequently a reduction in health problems $12,14,25,27,33,34,35,36,37,38,39$.

Mean BMI values increased in both genders over the course of ten years (Table 1), but mean BMI in females remained below that found in the $1^{\text {st }}$ National Health and Nutritional Survey of Brazilian Indigenous Peoples, a study that used a probabilistic sample of women 14 to 49 years of age and children under 60 months, living in villages in four major geographic regions of the country (BMI $\left.=25.2 \mathrm{~kg} / \mathrm{m}^{2} ; 95 \% \mathrm{CI}: 24.7 ; 25.8\right) 40$. When adjusted for age, in males there was a reduction in BMI with age, that is, older individuals showed lower mean body mass index. These results may be related to older males' non-adherence to the new living and eating habits that have occurred in the villages, or to the aging process itself. The $1^{\text {st }}$ National Health and Nutritional Survey of Brazilian Indigenous Peoples showed the opposite in women, an increase in BMI with age; however, the age range in the sample was lower than in the current study 40 . 
Number and percentage of Khisêdjê indigenous individuals evaluated in 1999-2000 and 2010-2011 according to occurrence of new cases of altered metabolic or nutritional profile during the period, according to gender. Xingu Indigenous Park, Central Brazil, 2013.

\begin{tabular}{|c|c|c|c|c|c|c|c|}
\hline \multirow[t]{2}{*}{ Variables/Categories } & \multicolumn{2}{|c|}{ Females } & \multicolumn{2}{|c|}{ Males } & \multirow[t]{2}{*}{ p-value * } & \multicolumn{2}{|c|}{ Total } \\
\hline & $\mathrm{n}$ & $\%$ & $\mathbf{n}$ & $\%$ & & $\mathbf{n}$ & $\%$ \\
\hline Metabolic syndrome & & & & & 0.112 & & \\
\hline No & 14 & 51.9 & 21 & 72.4 & & 35 & 62.5 \\
\hline Yes & 13 & 48.1 & 8 & 27.6 & & 21 & 37.5 \\
\hline Excess weight & & & & & 0.887 & & \\
\hline No & 19 & 70.4 & 13 & 68.4 & & 32 & 69.6 \\
\hline Yes & 8 & 29.6 & 6 & 31.6 & & 14 & 30.4 \\
\hline Central obesity & & & & & 0.005 & & \\
\hline No & 6 & 40.0 & 28 & 80.0 & & 34 & 68.0 \\
\hline Yes & 9 & 60.0 & 7 & 20.0 & & 16 & 32.0 \\
\hline Arterial hypertension & & & & & 0.629 & & \\
\hline No & 23 & 63.9 & 21 & 58.3 & & 44 & 61.1 \\
\hline Yes & 13 & 36.2 & 15 & 41.7 & & 28 & 38.9 \\
\hline Diabetes mellitus & & & & & 0.950 & & \\
\hline No & 32 & 97.0 & 35 & 97.2 & & 67 & 97.1 \\
\hline Yes & 1 & 3.0 & 1 & 2.8 & & 2 & 2.9 \\
\hline Hypercholesterolemia & & & & & 0.448 & & \\
\hline No & 19 & 76.0 & 20 & 66.7 & & 39 & 70.9 \\
\hline Yes & 6 & 24.0 & 10 & 33.3 & & 16 & 29.1 \\
\hline Low HDLc & & & & & 0.505 & & \\
\hline No & 2 & 66.7 & 1 & 100 & & 3 & 75.0 \\
\hline Yes & 1 & 33.3 & - & - & & 1 & 25.0 \\
\hline High LDLc & & & & & 0.084 & & \\
\hline No & 17 & 81.0 & 26 & 96.3 & & 43 & 89.6 \\
\hline Yes & 4 & 19.0 & 1 & 3.7 & & 5 & 10.4 \\
\hline Hypertriglyceridemia & & & & & 0.914 & & \\
\hline No & 13 & 52.0 & 7 & 53.8 & & 20 & 52.6 \\
\hline Yes & 12 & 48.0 & 6 & 46.2 & & 18 & 47.4 \\
\hline Hyperuricemia & & & & & 0.058 & & \\
\hline No & 32 & 94.1 & 25 & 78.1 & & 57 & 86.4 \\
\hline Yes & 2 & 5.9 & 7 & 21.9 & & 9 & 13.6 \\
\hline
\end{tabular}

HDLc: high-density lipoprotein; LDLc: low-density lipoprotein.

* Refers to $\chi^{2}$ test.

As identified with the excess weight variable, cumulative incidence of central obesity in the Khisêdjê was around $30 \%$, and was even more alarming in women $(60 \%)$. The protection against incidence of central obesity in males (RR = 0.33 ), independently of age, highlights the relevance of this outcome, which is associated with increased risk of cardiovascular diseases and other $\mathrm{CNCD} 22$ for females. An important hypothesis (but not investigated in the current study) is the high number of pregnancies among indigenous women over the course of their childbearing years. Data from the National Demographic and Health Survey of Brazilian Women and Children in 2006 showed that the highest prevalence rates of elevated waist circumference occurred precisely in women with the most children ${ }^{41}$. Another relevant limiting factor relates to the diagnostic criteria used to identify nutritional status and some metabolic conditions, which may not be appropriate for indigenous individuals.

Among the other target components, the study identified an increase in SBP in both genders and DBP in males, with increasing age 
Cumulative incidence ratios (CIR) by point and $95 \%$ confidence intervals (95\% Cl), adjusted simultaneously according to gender and age, for alterations in metabolic and nutritional profile in Khisêdjê indigenous individuals evaluated in 1999-2000 and 2010-2011. Xingu Indigenous Park, Central Brazil, 2013.

\begin{tabular}{lcccc}
\hline Variables (new cases of) & $\begin{array}{c}\text { CIR * } \\
\text { Age (in years) ** }\end{array}$ & $95 \% \mathrm{Cl}$ & $\begin{array}{c}\text { CIR * } \\
\text { 95\% }\end{array}$ & Gender (male vs. female) ** \\
\hline Metabolic syndrome & 1.01 & $0.98 ; 1.03$ & 0.57 & $0.28 ; 1.16$ \\
Excess weight & 0.98 & $0.94 ; 1.01$ & 0.96 & $0.41 ; 2.25$ \\
Central obesity & 0.99 & $0.96 ; 1.02$ & 0.33 & $0.15 ; 0.72$ \\
Arterial hypertension & 1.03 & $1.01 ; 1.05$ & 1.19 & $0.68 ; 2.07$ \\
Diabetes mellitus & 1.04 & $1.01 ; 1.07$ & 0.99 & $0.07 ; 15.02$ \\
Hypercholesterolemia & 1.02 & $0.99 ; 1.05$ & 1.37 & $0.58 ; 3.21$ \\
High LDLc & 1.10 & $1.04 ; 1.17$ & 0.18 & $0.02 ; 1.89$ \\
Hypertriglyceridemia & 0.98 & $0.95 ; 1.01$ & 1.03 & $0.52 ; 2.06$ \\
Hyperuricemia & 1.04 & $0.99 ; 1.08$ & 3.84 & $0.99 ; 14.95$ \\
\hline
\end{tabular}

* Robust Poisson regression adjusted simultaneously for age and gender;

** Reference: younger age (in years, collected in 1999-2000);

$\star \star \star$ Reference: female gender.

HDLc: high-density lipoprotein; LDLc: low-density lipoprotein.

(Table 2). These data contrast with the information published in 1988 by the Intersalt Study, which showed that in a sample of indigenous individuals from the Xingu $(\mathrm{N}=198)$ there was only a minor increase in SBP $(0.6 \mathrm{mmHg})$ and a decrease in DBP $(0.4 \mathrm{mmHg})$ with increasing age 41,42 . However, they partially corroborate the findings from the 1st National Health and Nutritional Survey of Brazilian Indigenous Peoples 40 showing that SBP, and DBP in females, increased statistically with age. Similar to the current study, another study among indigenous people from the Suruí ethnic group in the State of Rondônia, Brazil, showed a minor increase in mean SBP and DBP in both genders between 1988 and 2005, which only reached statistical significance for SBP in females 44 . Hypertension was the second most frequent incident disease $339.8 \%$ ) over the ten years of follow-up, and there was an increase of $3 \%$ for each year of life, independently of gender. These results may relate to changes in eating habits and lifestyle among the population. Mean SBP and DBP levels in the Khisêdjê, especially in 2010-2011, were higher than those observed in indigenous peoples of the Xingu as reported in the Intersalt Study 42,43.

Despite the low cumulative incidence (2.9\%) of diabetes mellitus over the ten years, these results are higher than the findings by Baruzzi ${ }^{3}$, who reported that as of 2002 only two cases of diabetes had been identified in the Xingu Indigenous Park, both in women from other ethnic groups. On the other hand, these findings are low- er than those reported by other authors reporting high incidence rates for diabetes mellitus (> 17\%) among different indigenous peoples around the world. Obesity, family history of diabetes, and genetic and environmental factors are related to the etiology of this disease $34,45,46,47,48,49,50,51$. A study of North American indigenous peoples from 13 different ethnic groups showed lower diabetes incidence among participants who reported any type of physical activity when compared to physically inactive individuals 49 . Based on these findings, the low incidence of diabetes found in the current study may be explained by the same factor, since recent data show that the Khisêdjê are physically active and in good shape 16,52.

Low HDLc is considered a strong independent predictor of coronary disease 27 . Among the Khisêdjê this was the most frequent condition both in 1999-2000 (88.9\%) and in 2010-2011 $(66.2 \%) 8,16$. In the current study, only one new case of low HDLc was identified in ten years. However, this incidence cannot be considered low, since it may been due to the fact that prevalence of the condition was already high at the beginning of the study, that is, few individuals ( $n=4$ ) were at risk of becoming new cases. A study in 2010 found that low HDLc may be related to genetic alterations in the metabolism of Native American peoples as a form of adaptive response to the environment 53 .

Although high LDLc was not the main lipid disorder found in the Khisêdjê in 1999-2000 or 2010-2011, the increase in its levels with increas- 
ing age emphasize the need for surveillance of this and other cardiovascular risk factors among these individuals. Likewise, the high cumulative incidence of hypertriglyceridemia $(47.4 \%)$ and high prevalence rates in this population expose the individuals to high cardiovascular and metabolic risks.

In general, the adoption of non-traditional foods, changes in patterns of physical activity and customs (such as the use of new technologies) and the increase in the family economy based especially on paid work and social position (socioeconomic status) are factors commonly related to the appearance of metabolic syndrome and other CNCD among indigenous and nonindigenous peoples $1,3,4,5,6,7,9,10,11,18,20,32,54,55,56,57$.

The study's potential limitations include the possible variation (under or overestimation) of cumulative incidence rates resulting from loss of follow-up of eight indigenous individuals from the beginning of the study $(9.3 \%$ of total eligible subjects). As an example, if the eight individuals had become cases of metabolic syndrome, the cumulative incidence would have been $45.3 \%$
(95\%CI: 32.8; 57.8), but if they had remained free of the syndrome, the incidence would have been $32.8 \%$ (95\%CI: 21.0 ; 44.6), while the figure found in the study was $37.5 \%$ (95\%CI: $24.4 ; 50.6$ ). Meanwhile, the exclusion of cases of diabetes mellitus identified in 2010-2011 via the oral glucose tolerance test and the fact that the test was not performed in 1999-2000 may have contributed to underestimation of the observed diabetes incidence.

The current study showed deterioration in many of the target health indicators. The high cumulative incidence rates for metabolic syndrome, hypertriglyceridemia, hypertension, central obesity, and excess weight among the Khisêdjê are alarming and predispose them to high risk of cardiovascular diseases. Although these results are not necessarily representative for identification of the deterioration of health indicators for all Brazilian indigenous peoples, they raise an alert concerning the need to implement effective interventions to protect these peoples from the acculturation that has encroached unfortunately on their daily lives over the years.

\section{Resumen}

El objetivo del estudio fue identificar la incidencia del síndrome metabólico y de enfermedades asociadas en la población Khisêdjê, que reside en el Reserva Indígena de Xingú, Mato Grosso, Brasil, durante los años de 1999-2000 a 2010-2011. Fueron incluidos 78 individuos con edad $\geq 20$ años. Los datos fueron evaluados a través de las pruebas estadísticas t de Student, regresión lineal múltiple y regresión de Poisson. La incidencia acumulada en los 10 años de seguimiento fue de 37,5\% de síndrome metabólico, 47,4\% de hipertrigliceridemia, 38,9\% de hipertensión arterial y 32\% de obesidad central. Independientemente del sexo, la edad está relacionada como factor de riesgo para la incidencia de hiper- tensión arterial, diabetes mellitus, y LDLc elevado. Ser de sexo masculino se constituye en un factor de protección para la incidencia de obesidad central, independientemente de la edad. Fueron identificados deterioros significativos en gran parte de los indicadores de salud evaluados en los Khisêdjê expuestos a riesgo cardiometabólico elevado. Este resultado puede estar relacionado con la alteración del estilo de vida tradicional de la población estudiada.

Síndrome X Metabólico; Enfermedad Crónica; Población Indígena; Incidencia 


\section{Contributors}

L. Mazzucchetti participated in the study planning, data collection, elaboration of the databank, statistical analysis, and writing of the manuscript. P. P. O. Galvão, M. L. S. Tsutsui, and K. M. Santos contributed to the study planning, data collection, elaboration of the databank for 2010-2011, revision, and writing of the manuscript. D. A. Rodrigues and S. B. Mendonça collaborated in the study planning, data collection, revision, and writing of the manuscript. S. G. A. Gimeno, the project coordinator, participated in the study planning, data collection (2010-2011), statistical analysis (1999-2000 and 2010-2011), and writing and revision of the manuscript.

\section{Acknowledgments}

The authors wish to thank the Khisêdjê people for participating in the study, the São Paulo State Research Foundation (FAPESP) for the financial support (grant no. 2010/52263-7), and the members of the Xingu Project at UNIFESP.

\section{References}

1. Gulgelmin SA, Santos RV. Ecologia humana e antropometria nutricional de adultos Xavánte, Mato Grosso, Brasil. Cad Saúde Pública 2001; 17:313-22.

2. Santos RV, Coimbra Jr. CEA. Cenários e tendências da saúde e da epidemiologia dos povos indígenas no Brasil. In: Coimbra Jr. CEA, Santos RV, Escobar $\mathrm{AL}$, organizadores. Epidemiologia e saúde dos povos indígenas no Brasil. Rio de Janeiro: Editora Fiocruz; 2003. p. 13-47.

3. Baruzzi RG. Do Araguaia ao Xingu. In: Baruzzi RG, Junqueira $\mathrm{C}$, organizadores. Parque Indígena do Xingu: saúde, cultura e história. São Paulo: Terra Virgem Editora; 2005. p. 59-112.

4. Leite MS, Santos RV, Gugelmin SA, Coimbra Jr. CEA. Crescimento físico e perfil nutricional da população indígena Xavánte de Sangradouro-Volta Grande, Mato Grosso, Brasil. Cad Saúde Pública 2006; 22:265-76.
5. Gimeno SGA, Rodrigues D, Pagliaro H, Cano EN, Lima EE, Baruzzi RG. Perfil metabólico e antropométrico de índios Arauák: Mahináku, Waurá e Yawalapití, Alto Xingu, Brasil Central, 2000/2002. Cad Saúde Pública 2007; 23:1946-54.

6. Lourenço ANP, Santos RV, Orellana JDY, Coimbra Jr. CEA. Nutrition transition in Amazonia: obesity and socioeconomic change in the Suruí Indians from Brazil. Am J Hum Biol 2008; 20:564-71.

7. Gimeno SGA, Rodrigues D, Cano EN, Lima EES, Schaper M, Lafer MM, et al. Cardiovascular risk factors among Brazilian Karib indigenous peoples: Upper-Xingu, Central Brazil, 2000-2003. J Epidemiol Community Health 2009; 63:299-304.

8. Salvo VLMA, Rodrigues D, Baruzzi RG, Pagliaro H, Gimeno SGA. Perfil metabólico e antropométrico dos Suyá. Parque Indígena do Xingu, Brasil Central. Rev Bras Epidemiol 2009; 12:458-68. 
9. Welch JR, Ferreira AA, Santos RV, Gugelmin SA, Werneck G, Coimbra Jr. CEA. Nutrition transition, socioeconomic differentiation, and gender among adult Xavánte Indians, Brazilian Amazon. Hum Ecol 2009; 37:13-26.

10. Anjos HNK, Toledo MJO, Mota LT, Previdelli ITS, Anjos AF, Saruhashi TR, et al. Prevalence of metabolic syndrome among Kaingang native Americans in Southern Brazil. Braz Arch Biol Technol $2011 ; 54: 81-9$.

11. Rocha AKS, Bós AJG, Huttner E, Machado DC. Prevalência da síndrome metabólica em indígenas com mais de 40 anos no Rio Grande do Sul, Brasil. Rev Panam Salud Pública 2011; 29:41-5.

12. Alberti KGMM, Ekel RH, Grundy SM, Zimmet PZ, Cleeman JI, Donato KA, et al. Harmonizing the metabolic syndrome: a joint interim statement of the International Diabetes Federation Task Force on Epidemiology and Prevention; National Heart, Lung, and Blood Institute; American Heart Association; World Heart Federation; International Atherosclerosis Society; and International Association for the Study of Obesity. Circulation 2009; 120:1640-5.

13. Sociedade Brasileira de Hipertensão; Sociedade Brasileira de Cardiologia; Sociedade Brasileira de Endocrinologia e Metabologia; Sociedade Brasileira de Diabetes; Associação Brasileira para Estudos da Obesidade. I diretriz brasileira de diagnóstico e tratamento da síndrome metabólica. Arq Bras Cardiol 2005; 84 Suppl 1:3-28.

14. Mottillo S, Filion K, Genest J, Joseph L, Pilote L, Poirier P, et al. The metabolic syndrome and cardiovascular risk a systematic review and metaanalysis. J Am Coll Cardiol 2010; 56:1113-32.

15. Oliveira GF, Oliveira TRR, Rodrigues FF, Corrêa LF, Arruda TB, Casulari LA. Prevalence of metabolic syndrome in the indigenous population, aged 19 to 69 years, from Jaguapiru Village, Dourados (MS), Brazil. Ethn Dis 2011; 21:301-6.

16. Santos KM, Tsutsui MLS, Galvão PPO, Mazzucchetti L, Rodrigues D, Gimeno SGA. Grau de atividade física e síndrome metabólica: um estudo transversal com indígenas Khisêdjê do Parque Indígena do Xingu, Brasil. Cad Saúde Pública 2012; 28:2327-38.

17. Cardoso AM, Mattos IE, Koifman RJ. Prevalência de fatores de risco para doenças cardiovasculares na população Guaraní-Mbyá do Estado do Rio de Janeiro. Cad Saúde Pública 2001; 17:345-54.

18. Tavares EF, Vieira-Filho JPB, Andriolo A, Sanudo A, Gimeno SGA, Franco LJ. Metabolic profile and cardiovascular risk pattern of an Indian tribe living in the Amazon Region of Brazil. Hum Biol 2003; 75:31-46.

19. Tavares EF, Vieira-Filho JP, Andriolo A, Perez AB, Vergani N, Sañudo A, et al. Serum total homocysteine levels and the prevalence of folic acid deficiency and C677T mutation at the MTHFR gene in an indigenous population of Amazonia: the relationship of homocysteine with other cardiovascular risk factors. Ethn Dis 2004; 14:49-56.
20. Coimbra Jr. CEA, Santos RV, Welch JR, Cardoso AM, Souza MC, Garnelo L, et al. The first national survey of indigenous people's health and nutrition in Brazil: rationale, methodology, and overview of results. BMC Public Health 2013; 13:52.

21. Pagliaro H, Mendonça S, Baruzzi R. Fecundidade e saúde reprodutiva das mulheres Suyá (Kisêdjê): aspectos demográficos e culturais. Caderno $\mathrm{CRH}$ 2009; 22:479-91.

22. World Health Organization. Physical status: the use and interpretation of anthropometry. Geneva: World Health Organization; 1995. (Technical Report Series, 854).

23. World Health Organization. Obesity: preventing and managing the global epidemic. Geneva: World Health Organization; 1998.

24. Genuth S, Alberti KG, Bennett P, Buse J, Defronzo R, Kahn R, et al. Follow-up report on the diagnosis of diabetes mellitus. Diabetes Care 2003; 26 : 3160-7.

25. Alberti KGMM, Zimmet PZ. Definition, diagnosis and classification of diabetes mellitus and its complications. Part 1: diagnosis and classification of diabetes mellitus provisional report of a WHO consultation. Diabet Med 1998; 15:539-53.

26. Friedwald WT, Levy RI, Fredrickson DS. Estimation of the concentration of low-density lipoprotein cholesterol in plasma, without the use of the preparative ultracentrifuge. Clin Chem 1972; 18: 499-502.

27. Expert Panel on Detection, Evaluation, and Treatment of High Blood Cholesterol in Adults. Executive Summary of The Third Report of The National Cholesterol Education Program (NCEP) Expert Panel on Detection, Evaluation, And Treatment of High Blood Cholesterol In Adults (Adult Treatment Panel III). JAMA 2001; 285:2486-97.

28. Kirsztajn GM. Avaliação do ritmo da filtração glomerular. J Bras Patol Med Lab 2007; 43:257-64.

29. Salvo VLMA. Aspectos nutricionais e metabólicos em população nipo-brasileira e Suyá [Tese de Doutorado]. São Paulo: Escola Paulista de Medicina, Universidade Federal de São Paulo; 2008.

30. Snedecor GW, Cochran WG. Statistical methods.

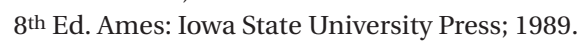

31. Rodrigues D. A UNIFESP/Escola Paulista de Medicina, o Projeto Xingu e a política de atenção à saúde dos povos indígenas no Brasil. In: Baruzzi RG, Junqueira $C$, organizadores. Parque Indígena do Xingu: saúde, cultura e história. São Paulo: Terra Virgem Editora; 2005. p. 259-73.

32. Pagliaro H, Carvalho NS, Rodrigues D, Baruzzi RG. Demographic dynamics of the Suyá, a Jê people of the Xingu Indigenous Park, Central Brazil, 19702004. Cad Saúde Pública 2007; 23:1071-81.

33. Resnick HE, Henderson J, Jones K, Lu W, Ruotolo $\mathrm{G}$, Jain AK, et al. Insulin resistance, the metabolic syndrome, and risk of incident cardiovascular disease in nondiabetic American Indians. Diabetes Care 2003; 26:861-7.

34. Pollex RL, Hanley AJ, Zinman B, Harris SB, Khan HM, Hegele RA. Metabolic syndrome in aboriginal Canadians: prevalence and genetic associations. Atherosclerosis 2006; 184:121-9. 
35. de Simone G, Devereux RB, Chinali M, Best LG, Lee ET, Galloway JM, et al. Prognostic impact of metabolic syndrome by different definitions in a population with high prevalence of obesity and diabetes: the Strong Heart Study. Diabetes Care 2007; 30:1851-6.

36. Gami AS, Witt B, Howard DF, Erwin PJ, Gami LA, Somers VK, et al. Metabolic syndrome and risk of incident cardiovascular events and death: a systematic review and meta-analysis of longitudinal studies. J Am Coll Cardiol 2007; 49:403-14.

37. Russel M, de Simone G, Resnick HE, Howard BV. The metabolic syndrome in American Indians: the Strong Heart Study. J Cardiometab Syndr 2007; 2:283-7.

38. Holewijn S, Den Heijer M, Swinkels DW, Stalenhoef AF, Graaf J. The metabolic syndrome and its traits as risk factors for subclinical atherosclerosis. J Clin Endocrinol Metab 2009; 94:2893-9.

39. McDermott RA, Li M, Campbell SK. Incidence of type 2 diabetes in two Indigenous Australian populations: a 6-year follow-up study. Med J Aust 2010; 192:562-5

40. Cardoso AM, Horta BL, Coimbra Jr. CEA, Follér ML, Souza MC, Santos RV. Inquérito Nacional de Saúde e Nutrição dos Povos Indígenas. Brasília: Fundação Nacional de Saúde; 2009.

41. Ministério da Saúde. Pesquisa nacional de demografia e saúde da criança e da mulher PNDS 2006: dimensões do processo reprodutivo e da saúde da criança. Brasília: Ministério da Saúde; 2009.

42. Intersalt Cooperative Research Group. Intersalt: an international study of electrolyte excretion and blood pressure. Results for 24 hour urinary sodium and potassium excretion. BMJ 1988; 297:319-28.

43. Carvalho JJ, Baruzzi RG, Howard PF, Poulter N, Alpers MP, Franco LJ, et al. Blood pressure in four remote populations in the Intersalt Study. Hypertension 1989; 14:238-46.

44. Tavares FG, Coimbra Jr. CEA, Cardoso AM. Níveis tensionais de adultos indígenas Suruí, Rondônia, Brasil. Ciênc Saúde Coletiva 2013; 18:1399-409.

45. Knowler WC, Saad MF, Pettitt DJ, Nelson RG, Bennett PH. Determinants of diabetes mellitus in the Pima Indians. Diabetes Care 1993; 16(1 Suppl):216S-27S.

46. Knowler WC, Pettitt DJ, Savage PJ, Bennett PH. Diabetes incidence in Pima Indians: contributions of obesity and parental diabetes. Am J Epidemiol 1981; 113:144-56.

47. Lee ET, Welty TK, Cowan LD, Wang W, Rhoades DA, Devereux R, et at. Incidence of diabetes in American Indians of three geographic areas. Diabetes Care 2002; 25:49-54.
48. Tulloch-Reid MK, Williams DE, Looker HC, Hanson RL, Knowler WC. Do measures of body fat distribution provide information on the risk of type 2 diabetes in addition to measures of general obesity? Diabetes Care 2003; 26:2556-61.

49. Fretts AM, Howard BV, Kriska AM, Smith NL, Lumley T, Lee TE, et al. Physical activity and incident diabetes in American Indians: the Strong Heart Study. Am J Epidemiol 2009; 170:632-9.

50. Ley SH, Harris SB, Mamakeesick M, Noon T, Fiddler E, Gittelsohn J, et al. Metabolic syndrome and its components as predictors of incident type 2 diabetes mellitus in an aboriginal community. CMAJ 2009; 180:617-24.

51. Wang Z, Hoy WE, Si D. Incidence of type II diabetes in aboriginal Australians: an 11- year prospective cohort study. BMC Public Health 2010; 10:487.

52. Tsutsui MLS. Aptidão e estado nutricional dos indígenas Khisêdjê, Parque Indígena do Xingu [Dissertação de Mestrado]. São Paulo: Escola Paulista de Medicina, Universidade Federal de São Paulo; 2013.

53. Acuña-Alonzo V, Flores-Dorantes T, Kruit JK, Villarreal-Molina T, Arellano-Campos O, Hünemeier $\mathrm{T}$, et al. A functional ABCAl gene variant is associated with low HDL-cholesterol levels and shows evidence of positive selection in Native Americans. Hum Mol Genet 2010; 19:2877-85.

54. Santos RV, Coimbra Jr. CEA. Socioeconomic differentiation and body morphology in the Suruí of Southwestern Amazonia. Curr Anthropol 1996; 37:851-6.

55. Rodríguez-Morán M, Guerrero-Romero F, BritoZurita O, Rascón-Pacheco RA, Pérez-Fuentes R, Sánchez-Guillén MC, et al. Cardiovascular risk factors and acculturation in Yaquis and Tempehuanos Indians from Mexico. Arch Med Res 2008; 39:352-7.

56. Moura PG, Batista LRV, Moreira EAM. População indígena: uma reflexão sobre a influência da civilização urbana no estado nutricional e na saúde bucal. Rev Nutr 2010; 23:459-65.

57. Bjerregaard P, Jørgensen ME; Greenland Population Study Group. Prevalence of obesity among Inuit in Greenland and temporal trend by social position. Am J Hum Biol 2013; 25:335-40.

Submitted on 19/Dec/2013

Final version resubmitted on 05/Mar/2014

Approved on 05/May/2014 